\title{
The Realization of Mediator Speech Acts in The Process Of Resolving Divorce Cases At The Religious Court In The Sidoarjo Region
}

\author{
Endratno Pilih Swasono ${ }^{1}$, Djatmika $^{2}$, Sumarlam $^{3}$, Miftah Nugroho $^{4}$ \\ \{endratno007@student.uns.ac.id\} \\ Linguistic Study Program, Postgraduate, Sebelas Maret University
}

\begin{abstract}
The purpose of this study is to describe the realization of the types of speech acts, the dominant types of speech acts and their functions that are often used by mediators in the process of settling divorce cases in the Religious Court of Sidoarjo region. Divorce is a social phenomenon because the divorce rate continues to increase every year, both in big cities and small cities like Sidoarjo. The Central Agency on Statistics for Public Relations of the Sidoarjo Religious Court said that from 2016 to 2019 the divorce rate increased from 4,500 to 5,962 cases. The Central Agency on Statistics said that from 2016 to 2019 East Java occupied the highest divorce rate in Indonesia. This problem has resulted in an accumulation of divorce case files and the judges taking extra work. There are currently the greatest number of divorce cases in the Religious Courts, but the success of mediating divorce cases is only about $2 \%$ of the 100 cases that are submitted every day in the Religious Courts. The type of this research is qualitative with a pragmatic approach. The active participation observation method is by recording, taking notes, and interviews with the mediator. Data analysis techniques used Spradley. The results showed that the mediator used types of assertive speech acts, directive speech acts and expressive speech acts in one divorce case. A directive speech act is a type of speech act that often appears and is often used in the process of resolving divorce cases at the Sidoarjo Regional Religious Court. Commissive and declarative speech acts in mediation are not used because they are not yet needed.
\end{abstract}

Keywords: speech act, Mediator, Disputing parties, Religious Court

\section{Introduction}

In general, language is used as a communication tool to express intentions and actions in human life. An expression that is manifested in the form of speech in the form of; words, phrases, clauses and sentences are considered as actions[1]. This research describes how the realization of speech acts, the dominant speech acts and their functions used by the mediator in mediating the process of resolving divorce cases in the Religious Courts. Mediation is a way of resolving disputes through the negotiation process to obtain agreement from the parties, assisted by a Mediator [2].

In the Supreme Court Regulation, it is stated that the mediator is a judge or other party who has a mediator certificate as a neutral party who helps the parties in the negotiation process to find various possibilities for dispute resolution without using a way to decide or force a 
settlement [3]. The following a piece of mediator conversation in the process of resolving divorce cases at the Sidoarjo Region Religious Court.

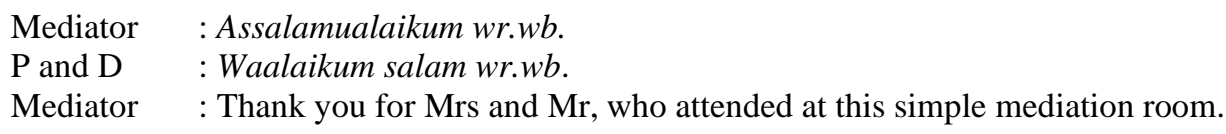

The mediator conversation above took place on Monday 17 June 2019 at 09.30 WIB at the Sidoarjo Regional Religious Court. The above speech occurred between the mediator, the plaintiff and the defendant when the mediator started the mediation with the speech of Assalamualaikum $w r, w b$, the plaintiff and the defendant responded by telling Waalaikum salam $w r, w b$. Next, the mediator also delivered a speech of thanks to the Mrs and Mr who attended this simple mediation room.

Greeting or thanking a mediator for initiating mediation to the plaintiff and defendant is a good starting point and the courtesy and speech used by the mediator is included in expressive speech acts. Expressive speech acts are speech acts that function to express or show a speaker's psychological attitude towards joy, sorrow, pleasure and displeasure in certain circumstances [4]. The example of conversation above is a realization of the types of speech acts used by the mediator in the process of settling divorce cases at the Religious Court in Sidoarjo region.

Many people study speech acts, but it is still interesting to study speech acts when the object and aspects of the study are different. The following are some literature with consecutive years related to this research, [5] Examines the effectiveness of mediation referring to Perma number 1 of 2008. [6] Examines the process of settling divorce cases through mediation at Makamah Syar'iyah Lhokseumawe. [7] Examines the. The effectiveness of mediation in settling divorce cases at the Jambi Religious Court. [8] His thesis examines the effectiveness of mediation in divorce cases at the Baubau Religious Court. [9] Examines the effectiveness of the role of mediation in resolving divorce cases within the Religious Courts. [10] Examines Divorce Mediation. [11] Reviewed the mediator's ability to support successful mediation in divorce cases at the Makassar Religious Court.

[12] examines the role of mediators and their function in resolving civil cases. [13] Studied the Effectiveness of Mediation in Resolving Marriage Conflicts at the Jombang Religious Court. [14] Her's dissertation examines a new approach to effectiveness in mediation. [15] Examined the effectiveness of mediators in using speech acts in mediation. [16] Examines the directive speech acts used by female mediators in mediation at the 1st level of the Religious Court in Padang. The object in Kamila's research is the female mediator and the aspect of the study is the directive speech act.

In contrast to this research, the object of research is on both male and female mediators, but the aspect of the study looks at the overall speech acts used by the mediator in mediation settlement. [17] Thesis examines Mediators and strategies for success in mediation. The empty space that can be used as a different research by looking at some of the previous studies is the realization of the mediator's speech acts in the divorce case settlement process at the Religious Court in Sidoarjo Region. 


\section{Research Methods}

This study uses a qualitative research type using a pragmatic analysis approach. The data of this research are the speech of the mediator and divorcing couples in dispute in the speech event of the divorce case settlement process at Sidoarjo Court. The data collection technique in this research is by participatory observation, namely the researcher follows the mediation room to become one of the participants in the direct divorce mediation without being involved in it to record, noting and in-depth interviews with the mediator. To check the validity of the data in this study, researchers used triangulation of data sources.

Sources of data in this study are the speech events of the divorce settlement process, both divorce, divorce and suing at the Sidoarjo Religious Court. The data analysis of this research was conducted qualitatively and inductively. The data were analyzed qualitatively because the researcher tried to analyze the conversations in the field to understand the form, meaning and function of the speech of the mediator and divorcing couples in conflict in the conversation of the divorce case settlement process at the Religious Court.

The interaction of the mediator and the conflicting divorcing couples is arranged and transcribed so that the data can be read easily after the data is obtained from the mediation record. Classifying and categorizing conversation data based on [18], then the data is interpreted based on the context of the situation [19] [20]. Inductive data analysis in this study was carried out in 4 stages according to the data analysis technique [19] [20].

\section{Results and Discussion}

The results showed that the types of speech acts used by the mediator based on Searle's 1969 theory in the process of solving divorce cases at the Sidoarjo Regional Religious Court in a divorce case can be seen in the following table:

Table 1. Results and discussion of mediator speech acts in the divorce case

\begin{tabular}{|l|l|l|l|}
\hline No & Type of Speech Acts & Number & Precentage \\
\hline 1 & Assertive & 20 & $13,6 \%$ \\
\hline 2 & Commissive & 0 & $0 \%$ \\
\hline 3 & Directive & 118 & $80,8 \%$ \\
\hline 4 & Expressive & 8 & $5,4 \%$ \\
\hline 5 & Declarative & 0 & $0 \%$ \\
\hline & Total & 146 & $100 \%$ \\
\hline
\end{tabular}

The table above can be explained as follows 146 mediator utterances divided into 20 or $13,6 \%$ data were assertive speech acts function to (informing, explaining, and affirming), 118 or $80,8 \%$ data were directive speech acts function to (asking, inviting, clarifying, asking / persuade / advising, confirming) and 8 or $5,4 \%$ data were expressive speech acts function to (giving greetings, gratitude, pray, take sholawat, apologize, quip). Directive speech acts are speech acts that often appear and are often used by mediators in the process of resolving divorce cases at the Religious Court in Sidoarjo region with 118 or $80,8 \%$ directive speeches in one talaq divorce case.

Mediator uses directive speech acts because they function to ask, invite, clarify, ask, persuade, advise, and confirm. Mediators rarely use commissive speech acts and declarative 
speech acts in mediation, because the mediator has not yet reached the commitment stage, read out the agreement or agreement during the mediation. The following is a snippet of the conversation as a representation of the realization of the mediator's speech acts in the process of resolving the divorce case at the Sidoarjo Religious Court.

\section{Assertive speech acts (informing)}

Assertive speech acts to tell are speech acts or expressions used by a speaker to tell the truth or belief to his speech partner. The speaker tells the speech partner because the speech partner doesn't feel or doesn't know his actions.

\section{Data 1}

Mediator: So, your husband wants to propose to the religious court if he wants a divorce. How do you respond?

Respondent : I accept, divorce.

The mediator uttered the speech in data 1 to the respondent with the intention of informing the respondent that the applicant (her husband) filed for divorce with the respondent properly and had been submitted to the Religious Court. Implicitly the speech delivered by the mediator asked the respondent to provide a response or answer, then the respondent said I accepted, divorced. The mediator's speech continues, your husband wants to propose to the religious court, he wants to divorce properly including the type of assertive speech act.

\section{Assertive speech acts (confirms)}

Confirming assertive speech acts are expressions of affirming what the speaker has believed to be true of the prepositions. The speaker gives confirmation to the speaker to understand what the speaker is supposed to do.

\section{Data 2}

Mediator : 900 right, how many times 3 months? 2,700,000, that's idah income, what might be reduced again, yeah

Applicant : don't have.

Mediator : : yeah..

Applicant : don't have.

Mediator : yeah, the calculation is to eat, we ask for food to you, ten thousand for one meal, how much is 3 times 30 thousand in one day, right for us to be normal humans, one month is 900,3 months is 2,700,000, right? only 3 months right.

The statement in data 2 occurs when the mediator confirms to the applicant about iddah living, which is the income that the husband must provide to his wife for 3 months when the husband talaq divorce. The mediator emphasized the iddah income because the applicant was confused and objected to the nominal money submitted by the mediator. The mediator confirmed the 3-month iddah income calculation to the applicant because the applicant did not respond well to the mediator.

The mediator's speech, he counted eating, the mediator asked him to eat, ten thousand for one meal, how many times per day is 3 times 30 thousand, right for us to be normal humans, one month is 900,3 months is 2,700,000 right? only 3 months, right? Entering the type of assertive speech act is emphasizing. The two data analyzes the types of assertive speech acts 
above are representative of the 20 data used by the mediator during the divorce case settlement process at the Religious Court in Sidoarjo region.

\section{Directive speech acts (asking)}

The directive questioning speech act is a speech act that requires the speaker to take an action or the speaker's willingness to respond to what the speaker is conveying.

\section{Data 3}

Mediator : So, your husband wants to propose to the religious court if you want a divorce. How do you respond?

Respondent : I accept, divorce .

The narrative in data 3 occurs when the mediator asks the respondent about his response, the applicant (husband) filed for divorce to the Religious Court with the mediator's speech, how did he respond? This speech was used by the mediator to get a definite answer from the respondent. The Respondent answered by saying I accept the divorce. The type of speech of the mediator above is included in the type of speech act of the directive asking.

\section{Directive speech acts (advising)}

A directive advising speech act is a speech act of giving input or advice to the speaker to do what the speaker says.

\section{Data 4}

Respondent : I accept divorce.

Mediator : just divorced, no need to divorce, you don't need it, she wants to go home, but don't be rude, she stops studying, no matter what is important in a good way full of responsibility, love your wife, what's your responsible?

Applicant : I have never been harsh, sir. Instead, she said harsh words, for example, she met a point.

The speech in data 4 occurred when the mediator gave advice to the applicant so that the applicant would like to cancel the divorce suit to the respondent because the respondent wanted to return home, wanted to leave college for the sake of his household. The mediator also gave advice to the applicant not to be too rude in speaking and responsible as head of household. The mediator's speech is just a divorce, no need to divorce, no need to let it go, I want to go home, but don't be rude, she stop to college no matter what is important in a good way full of responsibility, love your wife goes to kind of speech act advises directive. The example of speech act of the directive above is a representative of 110 mediator directive speech acts which are used as one of the utterances to resolve the divorce case process at the Sidoarjo Regional Religious Court.

\section{Expressive speech acts (thank you)}

Expressive speech acts of gratitude are speech acts that reveal the speaker's psychological state or feelings of pleasure to the speaker.

\section{Data 5}

Mediator $\quad$ : Assalamualaikum wr.wb ...

$\mathrm{A}$ and $\mathrm{R} \quad$ : Waalaikum salam wr.wb 
Mediator : Thank you to Mrs and Mr who came to this simple mediation room.

The statement in data 5 occurred when the mediator gave his thanks to the applicant and the respondent for coming to the mediation room. Appreciation with thanks is conveyed by the mediator to the disputing parties who also give the mediator confidence to help find a middle way or resolve ongoing household problems. Speeches of gratitude to the Mrs and Mr who were present in this simple mediation room included in the expressive type of thankful speech.

\section{Conclusion}

The conclusion of this research is:

a. There are 3 types of speech acts in the realization of the mediator's speech acts in the process of solving divorce cases at the Sidoarjo Religious Court, namely assertive, directive and expressive speech acts. Commissive and declarative speech acts do not appear in the realization of the mediator's non-speech in the mediation.

b. Types of speech acts that often appear and are used in the process of resolving divorce cases at the Sidoarjo Religious Court are directive speech acts with a total of 118 or $80.8 \%$ data. The realization of the speech acts of the mediator directive functions asking, inviting, clarifying, asking, cajoling, advising, and confirming. Overall, there are 16 functions of the mediator's speech act realization (informing, explaining, affirming, asking, inviting, clarifying, asking, cajoling, advising, confirming, greeting, thanking, praying, praying, apologizing, and insinuating)

c. The realization of speech acts can be used as one of the mediator's strategies to effectively and efficiently resolve dispute cases at the Sidoarjo District Court.

d. One of the objectives of the realization of the mediator's speech acts in the divorce case settlement process is to reconcile the disputing parties. Reconciling does not mean to unite or reconcile the couple who is going to divorce, but to reconcile finding solutions and seeking agreement after a conflict occurs in their household. The mediator only concludes from the desires, wishes, needs and problems faced by the husband and wife who are going to divorce, the decision to divorce or refer to the full rights of the spouse who is going to divorce.

Suggestion for mediators and researchers

a. The mediators can improve language competence in the pragmatic field in speech act strategies and understand the types of speech acts to be used in mediating.

b. The Researchers can add 2 to 4 more cases with different mediators, with the aim of obtaining more and different data in the realization of the mediator's speech act strategy, so that they can find out more complete types of speech acts.

\section{References}

[1] Austin, J.L.(1962). How to do thing with words. Harvard University Press: Cambridge, Mass.

[2] Hatta Ali, M. (2016). PERMA No 1. Tentang Prosedur Mediasi di Pengadilan. Amirpajatim Press.

[3] Hatta Ali, M. (2008, 2016). PERMA No 1. Tentang Prosedur Mediasi di Pengadilan. Amirpajatim Press.

[4] Rahardi, K. (2009). Sociopragmatik: Kajian Imperatif dalam Wadah Konteks Sosial Kultural dan Konteks Situasionalnya.Jakarta: Penerbit Erlangga. 
[5] Sofiani, T.(2010). Efektivitas Mediasi Perkara Perceraian Pasca Perma No 1 Tahun 2008 Di Pengadilan Agama. Jurnal Penelitian. Vol 7.No 2. Nopember 2010.

[6] Jumadiah. (2012). Proses Penyelesaian Perkara Perceraian Melalui Mediasi di Mahkamah Syar'iyah Lhokseumawe. Fiat Justitia Jurnal Ilmu Hukum. vol 6. No 2. Pp 1-12. Mei-Agustus 2012.

[7] Mustika, D.(2015). Efektivitas Mediasi Dalam Penyelesain Perkara Perceraian Di Pengadilan Agama Jambi. Jurnal AL-Risalah. Vol 15. No 2. Pp 297-308.

[8] Kahar Syarifudin.A. (2015). Efektivitas Mediasi Dalam Perkara Perceraian Di Pengadilan Agama Baubau. UIN Alaudin Makasar. Thesis

[9] Ibrahim, M. (2015). Efektivitas Peran Mediasi Dalam Menanggulangi Perceraian di Lingkungan Peradilan Agama. Jurnal Madania, vol: 9. No 1. P 105-118

[10] Emery, R. E. (2015). The truth about children and divorce. New York: Viking

[11] Reskiani, A. Lutfi, M.Hasan,H. (2016). Kompetensi Mediator Dalam Menunjang Keberhasilan Mediasi Pada Kasus Perceraian Di Pengadilan Agama Makasar ( Tinjauan teoritis dan faktual). Jurnal Diskursus Islam. Vol 04. No 2. Agustus 2016.

[12] Karmuji. (2016). Peran dan Fungsi Mediator dalam menyelesaika Perkara Perdata. Jurnal Ummul Qura Vol VII, No.1

[13] Mochamad Samsukadi, Ahmad Abdu. (2016). Efektifitas Mediasi dalam Menyelasaikan Konflik Pernikahan di Pengadilan Agama Jombang. Jurnal Hukum Keluarga Islam Volume 1, Nomor 1.

[14] Alysoun, Boyle. (2017). Effectiveness In Mediation: A new Approach. The New Castle Law Review. vol.12

[15] Yayat Dimyati, Hasyim Asy'ari, Mustoto. (2019). Efektif Mediator. Jurnal Mahkamah, Vol. 4, No.1. DOI: 10.25217/jm.v4i1.398 Heritage of Humanity. Jakarta: Senawangi, 2011

[16] Kamalia Muslim. 2019. Tindak Tutur Direktif Hakim Mediator Perempuan dalam Mediasi Perceraian di Pengadilan Agama Kelas 1A Padang. Jurnal Kata: Vol.3, No 2, Oktober 2019

[17] Jing li.(2019). Mediators' Strategies for a Successful Mediation. Thesis

[18] Searle, J.R. (1969). Speech Act: An Essay in the Philosophy of Language. Cambridge: Cambridge University Press.

[19] Spradely, John R. (1997). Metode Etnografi (penerjemah Misbah Zulfa Elizabeth). Yogyakarta : Tiara Wacana

[20] Santoso, R. (2017). Metode Penelitian Kualitatif Kebahasaan. Surakarta.UNS Press. 